\title{
An Investigation of School Improvement Specialist Coaches' (SISCs) Perceptions of INSET for Primary School English Language Teachers in Malaysia: Motivation, Practicalities and Challenges
}

\author{
E.L.L.Pang, D.Wray \\ Centre for Education Studies (CES) \\ The University of Warwick \\ Coventry, United Kingdom
}

\begin{abstract}
The Ministry of Education (MoE) in Malaysia introduced the Malaysia Education Blueprint (2013. 2025) to transform the education system. One of the aims was to upgrade the quality of in-service teacher training for teachers. This has resulted in a reshaping of the type of courses and delivery mode for in-service education and training (INSET) of teachers in a topdown, national priority driven training model. This research investigates the professional development needs of Malaysian primary school English language teachers. Teachers' perceptions of their professional development and the factors affecting it has so far been under-researched, at least in a Malaysian context. The research is informed by a qualitative survey approach investigating School Improvement Specialist Coaches' (SISCs) perceptions of their continuous professional development and learning $(C P D L)$ in their former role as primary school English language teachers. This research concerns SISCs' perceptions of the INSET they had previously attended, their future expectations of CPDL for primary school teachers, their perceptions of continuing professional development (CPD) in relation to pupils' needs in primary schools and their views on whether it had changed their practice in the classroom when they were practicing teachers in primary schools across different states in Malaysia. This paper focuses on the research participants' perceptions of factors which encouraged and supported them in their experiences of professional development which enhanced their skills and factors which demotivated them. In addition, this paper also addresses the SISCs'views of the practicalities and challenges of INSET for Primary school English language teachers in Malaysia.
\end{abstract}

\section{Introduction}

This paper reports the findings of a small scale qualitative study of the perceptions of a group of Malaysian teachers who have been promoted in their new role as School Improvement Specialist Coaches (SISCs) on in-service education and training (INSET) of English language teachers. They shared their perceptions of their professional development through attending INSET courses when they were primary school teachers. It focuses on the SISCs views of the factors which encouraged and supported them in their experiences of professional development by attending INSET as English language teachers as well as the factors which had demotivated them. This paper also addresses their views of the practicalities and challenges of INSET for English language teachers in Primary schools in Malaysia.

\section{Literature Review}

Pupils' achievement is strongly influenced by their parental background, a range of school factors and society or culture [1]. The teacher has been found to be the most important school factor influencing pupils' achievement [2], [3]. Teacher clarity, teachers' professional development and teaching strategies ranked highly in influencing pupils' academic achievement. Therefore, pupils' achievement can be raised if the quality of teachers improved.

The role of the teacher has come under scrutiny in recent years and the quality of teaching seems to depend upon their professional development. Research has shown that enhancing teacher quality through CPD is recognised as dynamic and continuous throughout a teacher's career [4].

Curriculum development and professional development are linked and no curriculum development can occur effectively without teacher development [5]. Teachers' professional development is viewed as a key school factor impacting students' achievement and learning outcomes. Curriculum development is complex, involving policies, goals, areas of study, units and lesson plans and is the reality of what is happening in schools. Teachers are central to the creation and development of the curriculum as they decide what to teach and when to teach it [6].

Professional Development is indeed a complex and long-term process and the best learning is slow learning [7]. There is also the question of the right 
teachers attending the right courses which is linked to the balance between individual teachers' needs, pupils' needs, schools and national needs. There are dangers in a top-down national priority driven structure of CPD as it is related to a shift from a knowledge and values base of education to the instrumentality of training [8].

In Malaysia, most INSET English language teachers use the cascade model, an apparently cost effective means to bring educational change to a large population of teachers with limited resources. Dissemination of a central approach is built into the initial learning process. Nevertheless, a smooth transfer of knowledge is not always achieved and the cascade model is not a guarantee of the training aims being applied to teach pupils in classrooms [9].

The training model of INSET is the dominant form of CPD used to train and re-train teachers [10]. Training and educating teachers is a problematic concept as there is a fine line between both but it is difficult to separate the two as they are related. Educating teachers helps them to decide what they need to do in the classroom including when they face challenges and training teachers helps them to do what is necessary in an effective, consistent and efficient manner. In Malaysia, the most common form of CPDL for English language teachers is formal CPD support which is planned and delivered by the Ministry of Education (MoE) Malaysia to teachers in the form of workshops and seminars for INSET.

According to Webster et al [11], when experienced teachers progress in their careers, their needs change alongside the rapid developments in education which require them to re-orientate themselves. McGill [12] suggests that teachers need to move from having a 'fixed mindset' to a 'growth mindset' as well as be open and willing to accept changes and take responsibility for their professional growth.

INSET has also been found to be more effective if it is delivered by experienced trainers and implemented as a whole-school approach supported by policies. Lieberman [16] believes teachers should have opportunities to try out new practices as this would encourage their growth and professional development.

\section{Focus of the Research}

The research participants in this study were a group of English language educators who had been teaching in primary schools in Malaysia for a duration between 10 to 30 years. They have recently been promoted and given the new role of School Improvement Specialist Coaches (SISCs) in 2014.

This paper addresses their perceptions regarding the factors which encouraged and supported them to enhance their skills through professional development by attending INSET courses for English language teachers during their careers. It also focuses on their views of the practicalities and the challenges of INSET in Malaysia for English language teachers at primary level. Their views will be linked to their previous INSET experiences when they were teachers, their future expectations of INSET for English language teachers and the professional development which is carried out using the cascade model in Malaysia.

\section{Research Method}

The broader research within which the present study was located is informed by the qualitative paradigm to determine diversity in a given population. The qualitative survey approach establishes variation in terms of values and dimensions that are meaningful within that population [17]. The broader research focused on findings from six focus groups and two individual interviews with 16 research participants which examine the research participants' perceptions of their previous and current experiences of attending INSET and their future expectations in relation to their role as English language educators.

The data was gathered through focus group interviews which used a topic guide and prompting questions which were parallel to the interview questions used for the individual interviews for case studies. Each focus group interview was carried out for about an hour and fifteen minutes and each research participant in the case studies took part in two individual interviews. The first interview focused on questions about the research participants' previous experiences of attending INSET and the second interview focused on their views about the intervention INSET course and their future expectations of INSET and CPDL.

This paper presents the findings from one focus group and four individual case studies which addresses the research participants' perceptions of the various factors in relation to INSET which encouraged and supported them in their professional development as well as some factors which demotivated them in relation to INSET. In addition, this paper also presents their views on the practicalities and challenges of INSET for English language teachers in rural and urban primary schools in Malaysia.

\section{Sampling}

The study took place in an INSET Training Centre under the Teacher Education Division, MoE Malaysia from May to July 2015. The research participants came from a variety of locations in Malaysia but attended the INSET course in one central location. This paper focuses on the data gathered from one focus group and four research participants selected from one group of educators who attended an INSET 
programme, the 'Specialist Certificate in Literacy Development for Lower Primary Students'.

The participants were initially selected using convenience sampling as they were in a group of 30 educators pre-selected by the English language officers (ELOs) in their State Education Department for the INSET programme. However, the actual sample who attended and completed the programme comprised 22 educators. During the first meeting with the researcher, consent forms were given to all the course participants and 11 people agreed to take part in the study. The researcher also gave them profile questionnaires to obtain specific demographic information such as the research participants' academic qualifications, teaching experience and INSET previously attended. The researcher then used this information and selected seven participants to take part in focus group interviews using purposive sampling based on criteria including gender, teaching experience, type of schools they have taught in as well as types of CPD activities attended in the last two years. In the next stage, four participants were selected for the individual interviews using volunteer sampling.

\section{Findings}

This section covers the findings from one focus group interview and individual interviews with four research participants.

\subsection{Focus Group}

The research participants who took part in Focus Group 1 in this study comprised three SISCs and their demographic details are seen below in Table 1.

Table 1. Research participants

\begin{tabular}{|l|c|c|c|}
\hline $\begin{array}{c}\text { Research } \\
\text { Participants }\end{array}$ & Gender & $\begin{array}{c}\text { Teaching } \\
\text { Experience } \\
\text { (years) }\end{array}$ & $\begin{array}{c}\text { School// } \\
\text { District }\end{array}$ \\
\hline A1- Tara & F & $26-30$ & Rural \\
\hline A2 - Alya & F & $11-15$ & Urban \\
\hline A3 - Hana & F & $26-30$ & Rural \\
\hline
\end{tabular}

In relation to the factors which motivated and encouraged the research participants to attend INSET and progress in their professional learning process, all three participants in the group agreed that they prefer short INSET courses with a duration of about three days in a venue which is within their states or the same region. For example; still within the Northern states in West Malaysia. On the contrary, they acknowledged the challenges they face related to the need for them to attend INSET programmes which were conducted in the capital city and other major towns and they spent a lot of time on travelling. They also had to attend briefing sessions at night and at times, their weekends had been taken away due to travelling for INSET. One of the participants explained that she has given up four weekends in a month as she was travelling to attend INSET and it is taking a toll on her work of teaching, coaching and mentoring. The research participants in the focus group explained that what would be practical is to plan and conduct INSET during the school holidays so that they can focus on their work during term time.

In relation to the opportunity to attend INSET and the number of days allocated for them to attend INSET each year, all the three research participants agreed they are demotivated sometimes to attend INSET as they are very often directed to attend INSET programmes, receiving an appointment to attend at least 9 out of 10 INSET courses. They also do not have a choice on topics or types of INSET, such as face-to-face workshops, online courses, professional learning communities etc. In addition, two of the participants explained that they are required to attend up to seven days of INSET annually but each of them have already attended INSET for 21 and 25 days respectively.

The participants shared that their English language officers (ELOs) in their State Education District Offices have the authority to appoint them officially to attend INSET and if there is an emergency situation, they can inform the officer and another person would replace them for the INSET course. They all agreed that the planning of INSET at a higher level reduces flexibility and is not practical as teachers do not get to decide when is the best time for them to attend INSET. With reference to the intervention INSET course they are currently attending for SISCs, the research participants explained that they all have hectic schedules in their new roles as SISCs and are trying to cope with the demands of the role as well as attend INSET frequently in the current year.

The focus group participants also shared they did not have a choice on the type of INSET they get to attend when they were teachers. Thus, they were not able to choose INSET programmes based on their pupils need or their needs. They also did not have their choice to choose INSET based on content or skills as well as whether it was generic INSET courses or INSET programmes specific to certain content such as Phonics or Language Arts.

One of the members in the group mentioned she preferred online courses for INSET but there is also the time constraint factor. Two of the group members stated that they prefer more content specific courses because they have been attending more generic INSET courses and another member shared that she is glad that she has attended a balanced amount of generic and content specific INSET courses. The research participants shared that they are comfortable with the current provisions of their professional development and learning as they are not ready to pay 
for other CPD activities that they could source on their own. Indirectly, they do feel well supported and encouraged to improve their skills through INSET as the programmes have been planned for them and is organized at a state or national level.

The findings from the individual interviews in from four case studies are as follows:

\subsection{Interviews}

6.2.1. Participant A: Rita. Rita is a female educator with over 26 years of teaching experience in semiurban primary schools in Malaysia. She prefers attending short INSET courses for about 3 to 4 days as it is not too demanding on her schedule. In her opinion, one of the factors which promoted her professional development from attending INSET is the opportunity to engage with enriching activities and read scholarly articles. In addition, Rita also received information from the trainers about upcoming INSET courses and could plan the direction of her professional development journey.

In relation to some of the perks of CPDL, Rita explained that the activity of sharing in small groups helped her to engage with the content of the course before the course participants did group presentations. She found it easier to open-up to the members in small groups and discuss issues and questions related to tasks given by the trainer. Rita also emphasized that about $80 \%$ of the INSET courses she has attended met her expectations. She felt she was well supported and thus was able to share what she gained with other teachers. The practice of sharing led some of them to be open to embrace change by trying out new activities or teaching strategies to improve their craft of teaching.

In terms of the practicalities of planning for INSET in Malaysia, Rita shared that all teachers and educators did not have to pay to attend the INSET courses provided by the MoE. The travel expenses for her to travel from her school to the course venue, whether within the same district or out of the state were always reimbursed. In addition, all other costs such as accommodation, meals and training materials were also provided by the organizer of INSET courses in conjunction with the MoE, Malaysia.

in relation to her professional development. The first challenge is linked to the directive to attend INSET courses. The practice in place is for the English language officers (ELOs) at the State Education Department to select teachers or educators to attend INSET courses. A list of the suggested names of course participants is prepared and sent to the CPD provider. The teachers would also receive letters to inform them about their appointment to attend the INSET course. Thus, the teachers or educators do not have the choice to select or volunteer to attend a specific INSET course which is relevant to them based on their individual preferences.
Rita also explained she found it particularly intensive in 2015 when she had to attend too many INSET courses and put various tasks on hold. She realised some of the INSET courses were too demanding as compared to previous INSET courses as there are new components including preparing action plan, carrying it out and completing an assessment component. In addition, she realized that the same course participants were instructed to attend various INSET courses. Thus, some teachers were called frequently to attend INSET and others are seldom given the opportunity. Rita shared she noticed that the list of names of the participants for different INSET courses are usually the same people from a particular district in a state. This could lead to one of the challenges for some practitioners to progress in their professional development as there is a lack of even distribution in terms of opportunities for teachers to attend INSET for their CPD.

6.2.2. Participant B: Siti. Siti is a female educator who has been teaching for between 11 to 15 years in rural primary schools. She shared that one of the factors which encouraged her for INSET is being nominated to attend courses held in capital cities such as Kuala Lumpur and Penang and all costs were subsidized. She does not mind being instructed to attend INSET which is compulsory as she needs the knowledge and the certificate. She shared that all the INSET she has attended is relevant to the new Standard-Based Primary School Curriculum (KSSR) which was introduced in 2011 together with School Based Assessment (SBA). She also stated that the previous INSET attended were relevant to her pupils' needs and she would rank most of the INSET courses with a score of 8 out of 10 as they focused on content and are conducted via workshops.

Siti also felt more motivated to progress in her professional development after being selected to attend three conferences which were fully sponsored by the State Education Department. She explained that this could be the benefits of teaching in a small rural school which only has about 150 students and two English language teachers. Thus, even on rotation basis, both she and the other English language teacher had the opportunity to attend INSET programmes frequently.

Apart from factors which supported Siti in her professional development, she shared the main factor which demotivated her in CPDL is attending the same course on the KSSR syllabus every year and not having a choice to attend other INSET courses. This is related to the challenge for her to have opportunities to attend INSET which is more specific to her needs and her pupils needs, such as content specific INSET with a focus on TESOL. Siti stated that she still needs to attend INSET for English Literature as well as Phonics because she requires the knowledge to improve her practice in these areas. She also 
mentioned that she does not prefer lectures during INSET as she often faced difficulty in following what is being delivered through mass lectures. She also prefers hands-on activities during workshop sessions as the other research participants.

6.2.3. Participant $\mathbf{C}$ - Lily. Lily is a female educator with more than 30 years of teaching experience in urban primary schools. She explained that what encouraged her to attend INSET was the opportunity she had previously to attend INSET frequently when she was teaching in a rural area. One of the courses had facilitators who were native speakers and the content was relevant to her pupils needs as it focused on the 4 basic skills; listening, speaking, reading and writing. Lily explained she had to accumulate 16 credit hours in order to complete the INSET programme. She felt that teachers from rural schools were given the priority to attend INSET as it was perceived they needed more assistance and coaching to improve in their pedagogical practice.

In addition, Lily prefers to travel outstation, to other towns out of her state for INSET as she would be able to interact with educators from other regions in Malaysia and discuss ideas with them and receive peer feedback. Lily believes the learning process is ongoing and she could learn from peers who are facing similar problems in relation to pedagogy and practice. Thus, there is support within a community of practice. She shared about the time when she was a teacher and whenever any one of her colleagues attended INSET at the district level, the teacher would conduct an in-house training session in school after completing the INSET course. She considers this a professional learning community (PLC) within a group of English language teachers in the same school. Nevertheless, she explained that when a teacher attends an INSET programme for a few days, the in-house session in school would have the content watered down through a session of two hours.

In contrary to being supported for INSET, Lily explained that since moving to an urban setting, the biggest challenge she faced is not being offered to attend any INSET by the State Education Department and neither has she paid to attend INSET courses run by private organizations as it is costly. In relation to the practicalities of INSET and what is needed, Lily shared that at present, teachers are in critical need to attend INSET which would guide them on how to use the assessment component and provide students with feedback. This is because feedback is a new component introduced in the KSSR curriculum. Thus, teachers' needs on getting current information, guidance and support on implementing the assessment component is vital for INSET providers to include in their planning of INSET for English language teachers at primary level.
6.2.4. Participant D - Muthu. Muthu is a male educator who has been teaching for about 30 years in urban primary schools. He explained that the factors which encouraged and supported his professional development is attending INSET which comprises workshops are hands-on activities which could be carried out in the classroom. He likes CPDL with practical activities which can be used after completing INSET courses.

In addition to attending INSET by MoE Malaysia, the teachers in Muthu's previous school attended INSET based on a rotation basis and they often had in-house training sessions on Saturdays, with discussion among the English panel members. Muthu has also paid to attend INSET courses offered by the Penang English Language Teacher Association (PELTA) as it is affordable and the courses are run by facilitators from the British Council. He strongly feels that he fully utilizes the content he learnt from INSET courses which he has chosen to attend.

Apart from the perks of INSET and CPDL, Muthu highlighted that the factor which demotivates his professional development is having the ELOs select INSET programmes for educators without considering their interest and needs. He explained that all teachers in schools in Malaysia fill in their annual assessment form with CPD courses they need and hope to attend these INSET courses in the following academic year or the future. However, he has not been given the opportunity to attend INSET courses related to his needs which he has stated. He shared that this practice does not cater to the needs of some course participants for any INSET course and thus sees it as a waste of time.

In relation to the content of INSET programmes, some of the activities and examples delivered by trainers during INSET is applicable to western countries and foreign contexts and the ideas suggested are not always suitable to be applied to the local setting in Malaysian schools. Muthu explained that the teachers would need to do more planning to adapt the content or pedagogical strategies suggested before applying them in the classroom for their pupils. Thus, course participants of INSET have a huge responsibility to plan, adapt and re-plan how they are going to use the new knowledge and resources. However, there is also the question of how many teachers are ready to get out of their comfort zone and invest more time in their planning and making changes in their teaching approaches as well as creating new content and materials for their daily teaching.

Muthu has also found the new component of assessment for INSET for all course participants too demanding as course participants need to do an online assessment, prepare an action plan and carry it out as well as write a reflection of 3000 words. He found that some teachers may need more time to adjust to this new model of INSET. 


\section{Discussion and Conclusion}

Based on the findings from the four case studies presented in this paper, the following themes emerged from the data.

\subsection{Professional Up-skilling}

One of the main aims of INSET initiatives in Malaysia by the MoE is to develop the English language proficiency and teaching skills of English language teachers. This is in line to improve the quality of teachers with proficiency in English. The new INSET courses at ELTC includes a component of assessment for participants and they need to complete an online assessment, prepare an action plan, implement it and write a reflective essay to be included in a portfolio of tasks for submission.

The research participants in the focus group revealed that in the last once year up until July 2015, they had attended more than the required seven days of INSET activities. They have had many opportunities to attend INSET and two of them have spent more than 20 days attending INSET courses. The provisions of continuous opportunities for INSET have motivated them to progress and develop in their roles as educators. One of the participants in the focus groups mentioned that she would also like to attend conferences other than INSET courses as part of her CPDL.

Based on the individual interviews, Rita and Muthu shared similar views that the structure of the INSET courses has changed as previously they only had to participate in INSET by attending the programme and received a certificate of completion. At present, they both found the new model of INSET with an assessment component too demanding for the course participants. In addition, the last year has been very intensive for them as they were assigned to attend many INSET programmes and had to put work related tasks on hold. Nevertheless, the new assessment component of INSET was included as it is vital to aid in developing and enhancing the pedagogic competence of the course participants who attend INSET.

On the other hand, Siti shared that the quality of INSET offered is good but she has been attending the same INSET course on KSSR annually and would like to participate in INSET on Phonics and Literature as it would cater to her current needs. Similarly, Lily has not been able to attend INSET since moving from a rural school to an urban context. She explained that the provision for INSET is not balanced for educators in rural contexts and bigger towns. On a positive note, Siti shared that she was glad to attend three conferences for her CPDL and hopes there will be more opportunities in the future.

\subsection{INSET and Collaborative Learning}

Collaborative learning in INSET provides educators the opportunity to engage in formal and informal discussions about pedagogy. They usually work together to plan and design new activities using effective teaching strategies or to modify and adapt them to suit different learners' needs. Thus, collaboration is prioritised during the workshop sessions and there is collective ownership of the task completed in groups. Harris and Jones [18] emphasized that in the classroom, teachers can evaluate their teaching with purposeful collaboration. It can be effective especially when they use their knowledge, skills and understanding as well as data of students' achievement, thus linking improvements for the student and teacher.

The participants in the focus group agreed that when they travel outstation to towns in other states for INSET, it may seem like a waste of time as they use a lot of time for travelling. However, the advantage is being able to meet other teachers and network with them with regards to CPDL and sharing best practices.

Three case studies in this paper have shared about collaborative learning. Rita gave an example of how she was able to share knowledge she gained with other teachers in her district and some of them were keen to embrace change. This is in line with the point by William and Leahy [19] that the process of teacher change needs continuous support after INSET. Lily prefers to travel to the cities for INSET as she could exchange ideas and share views with educators from other states and districts. Muthu attends additional INSET on his own which is offered by PELTA in his state for a small fee by trainers from the British Council. He found it necessary to take control and plan the specific time and period in the year when he is free to attend these courses. He strongly feels that during CPDL, he had the opportunity to meet other participants and learn by discussing about common issues faced in the classroom and share solutions to address them with each other.

\subsection{Professional Practice and Professional Learning}

According to Kabilan and Veratharaju [20], the teachers in their study wanted more relevant professional development programmes which would enhance their current knowledge and skills as well as give them the opportunity to acquire more knowledge and new skills. This would enable them to achieve classroom efficacy and address changes they need in their practice to improve the teaching and learning process [21].

One of the participants in the focus group explained that she found INSET in the form of online 
courses useful as she gets feedback from the trainer and interact with other course participants via the online forums. She shared that she has completed around 10 online courses and finds it an interesting way to improve her knowledge and skills through an online mode of learning. The other participants agreed that they would need to find the time to participate in online courses out of their working time, time with their families and it involves multi-tasking. They all agreed that they have much more to learn through INSET in order to be competent with the necessary skills and be updated regularly with new information on pedagogical skills and content knowledge. At the same time, it was found that the participants realized that they have been learning to improve in their practice from on the job experiences as well as from INSET.

Based on the data from the case studies, Rita explained that she found it very helpful to share in small groups during INSET and this has fostered her way of learning from and with other course participants. She also currently practices introducing small group activities in other programmes she works on for coaching and mentoring other primary school English language teachers within the district. Thus, her experience of learning in small groups has been transferred to her professional practice and learning. Siti and Lily both had the experience of teaching in a rural area and a small school in a non-urban setting. They agreed that there were more opportunities for them to attend INSET while posted in a rural setting and they managed to developed in their professional learning from attending INSET frequently. In addition, they felt the CPD planners and ELOs felt teachers in rural schools needed more assistance in the form of INSET so that they could help to target their pupils needs and the schools needs for school improvement. Muthu explained why he regularly attends INSET by PELTA on his own and does not mind paying the fees to attend. Apart from INSET provided by MoE, he shared that he wanted to attend that were more specific to his needs and he believes that he fully utilizes the knowledge gained from selecting INSET activities of his own. He also shared that for some of the other prescribed INSET programmes, the content that he usually finds helpful to him was about $50 \%$ or less from the whole course. Thus, some teachers might become non-committal or skeptical towards some INSET programmes [20].

\section{Conclusion}

In conclusion, the research participants from the focus group and interviews in this small-scale research have identified factors which have encouraged them and supported their growth in professional development as well as issues which are seen as challenges while attending INSET to progress at the pace they had hoped for to improve their practice and craft of teaching. The research participants have highlighted some pertinent issues related to their CPDL, especially pupils' needs in urban and rural schools which contribute to teachers' needs and interests in INSET.

The role of educators and their professional development are closely linked to other areas such as varied teaching contexts and provisions available for INSET. These factors influence the way how educators value the nature of teaching and the continuous support they receive during and after INSET. Some of the important contribution in this study are the findings which suggests that educators are motivated to improve in their practice. They also demonstrated they are aware of their current INSET needs and wish to attend INSET which are more specific to their needs and pupils needs. Some of them also show initiatives to attend privately sourced INSET and participate in online courses to gain more knowledge and new skills to keep up with current pedagogies.

\section{References}

[1] Desforges, C. and Abouchaar, A., (2003). The Impact of Parental Involvement, Parental Support and Family Education on Pupils Achievement and Adjustment: A Literature Review. Research Report No. 433.

[2] Hargreaves, A. and Fullan, M., (2012). Professional Capital: Transforming Teaching in Every School. USA: Teachers College Press.

[3] Mincu, M., (2013) Teacher Quality and School Improvement: What is the Role of Research? Research and Teacher Education: The Bera - RSA Inquiry. British Educational Research Association.

[4] Schleicher, A., (2011). The Quality of an Education System Cannot Exceed the Quality of its Teachers. Journal of Teacher Education March/April 2011 vol. 62 no. 2 202221.

[5] Stenhouse, L., (1989). An Introduction to Curriculum Research and Development. London: Heinemann Educational Books Ltd.

[6] Macalister, J. and Nation, I.S.P., (2011). Case Studies in Language Curriculum Design. Concepts and Approaches in Action Around the World. USA: Routledge.

[7] Neil, P. and Morgan, C., (2005). Continuing Professional Development for Teachers: From Induction to Senior Management. Great Britain: Taylor \& Francis elibrary.

[8] Graham, J., (1996). The Teacher Training Agency: Continuing Professional Development Policy and the Definition of Competencies for Serving Teachers. British Journal of In-Service Education, Volume 22, No. 2, pages 121-132. 
[9] Wedell, M., (2005). Cascading Training Down into the Classroom: The Need for Parallel Planning. International Journal of Education Development. Volume 26. Issue 6. Page 637-651.

[10] Kelly, P. and McDiarmid, G. W., (2002). Decentralisation of Professional Development: Teachers' Decisions and Dilemmas, Journal of In-Service Education, 28, page 409-425.

[11] Webster, A., McNeish, D., Scott, S., Maynard, L. and Haywood, S., (2012). What Influences Teachers to Change their Practice? A Rapid Research Review. Short Policy Report No. 12/07. Centre for Understanding Behaviour Change. United Kingdom: National Centre for Social Research for CUBeC.

[12] McGill, R. M., (2013). Professional development for teachers: how can we take it to the next level? Professional Development, Teachers Blog in The Guardian, 29 January 2013

[13] Wheller, L. and Morris, J., (2010) Evidence Reviews: What Works in Training, Behaviour Change and Implementing Guidance? NPIA Research, Analysis and Information (RAI) Unit.

[14] Cordingley P., Bell M., Rundell B., Evans D., (2003). The impact of collaborative CPD on classroom teaching and learning. In: Research Evidence in Education Library. London: EPPI-Centre, Social Science Research Unit, Institute of Education, University of London.

[15] Ball, S., (1984). "Motivation: Some Reflections \& Projections." In R.E. Ames, \& C. Ames (eds). Research on Motivation in Education. New York: Academic Press, Inc.

[16] Lieberman, A., (1995). Practices that support teacher development: Transforming conceptions of professional learning. Phi Delta Kappan 76(8), 591-596.

[17] Jensen, H., (2010) The Logic of Qualitative Survey Research and its position in the Field of Social Research Methods. Forum: Qualitative Social. Volume 11, No.2 Art. 11-May 2010.

[18] Harris, A. and Jones, M., (2012). Connecting Professional Learning: Leading Effective Collaborative Enquiry across Teaching School Alliances, National College for School Leadership, UK.

[19] William, D. and Leahy, S., (2014). Sustaining Formative Assessment with Teacher Learning Communities. USA: Learning Sciences Dylan William Center.

[20] Kabilan, M.K. and Veratharaju, K., (2013). Professional Development Needs of Primary School English Language Teachers in Malaysia. Professional Development in Education, Volume 39: Issue 3. Pages 330 -351 .

[21] Darling-Hammond, L. et al., (2009). Professional Learning in the Learning Profession: A Status Report on Teacher Development in the United States and Abroad. Dallas, TX: National Staff Development Council. 